\title{
Monitoring of Vertical Deflection and Moisture Contents in Korean Traditional Timber Houses
}

\author{
Yeong-Min Kim \\ College of Architecture, Myongji University, South Korea
}

Copyright $(\mathcal{C} 2015$ by authors, all rights reserved. Authors agree that this article remains permanently open access under the terms of the Creative Commons Attribution License 4.0 International License

\begin{abstract}
In this research, surface moisture contents of columns and roof deflection of three Korean traditional timber houses were monitored. The monitored houses are composed of two different types of Hanok, that is, a one-story traditional Hanok built by traditional construction method, and two two-storied new-styled Hanok built by modernized construction method. The monitoring of traditional Hanok and new-styled Hanok1 has been carried out for about two and a half years, and that of the new-styled Hanok 2 is 14 months. The monitored moisture contents were analyzed according to column location to the sun, wood types and relative humidity. The moisture contents of the northern columns are $0.71 \%$ higher than those of the southern columns, and moisture contents of raw wood was $0.83 \%$ higher than that of the glued structural wood. The mean vertical deflection of angle rafters is $11.6 \mathrm{~mm}$ in traditional Hanok, $4.2 \mathrm{~mm}$ in new-styled Hanok1 and $2.1 \mathrm{~mm}$ in new-styled Hanok2. Meanwhile, the mean vertical deflection of plane rafters is $21.5 \mathrm{~mm}$ in traditional Hanok, $9.7 \mathrm{~mm}$ in new-styled Hanok1 and $20.3 \mathrm{~mm}$ in new-styled Hanok2. Angle rafters and plane rafters showed meaningful deformations and that were affected mainly by roof weight and supporting member.
\end{abstract}

Keywords Korean Traditional Timber Houses, Monitoring, Moisture Contents, Roof Deflection

\section{Introduction}

The Korean traditional timber house is called Hanok. The main structure of Hanok is a post and lintel timber frame. The connection types of the traditional Hanok are mainly mortise and tenon joints of only wood, and roof weight of the traditional Hanok is about $5 \sim 10 \mathrm{kN} / \mathrm{m}^{2}$, which is somewhat heavy in timber structure. On the other hand, new-styled Hanok, which is a modernized Hanok, to fit for the contemporary life styles has been developed recently. The new-styled Hanok has steel plate and bolt joints and light roof weight of about $2 \sim 3 \mathrm{kN} / \mathrm{m}^{2}$. The structural members used in traditional Hanok are generally raw wood, but the new-styled Hanok generally uses glued structural wood.

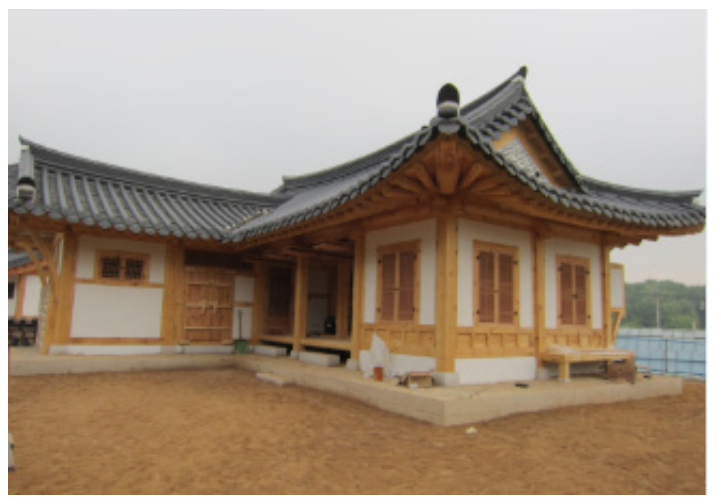

(a) Traditional Hanok

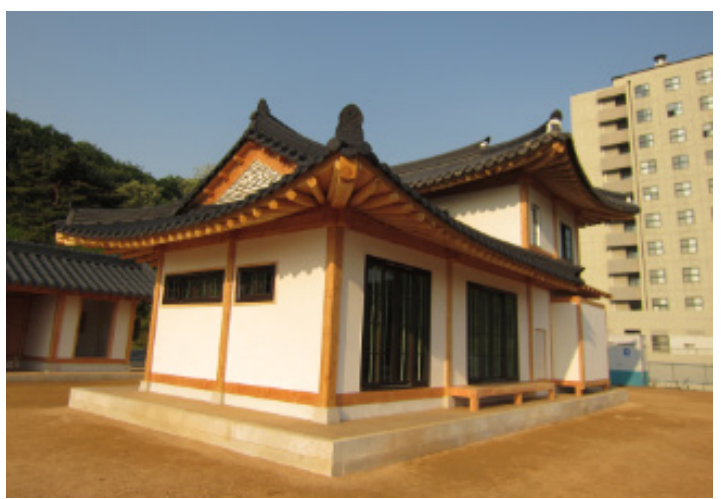

(b) New-styled Hanok1

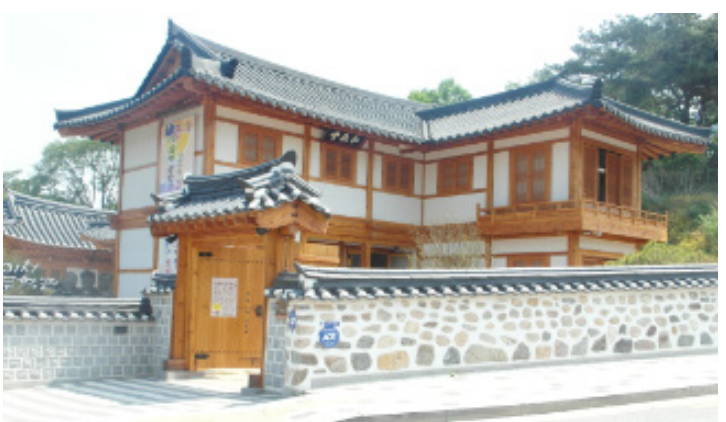

(c) New-styled Hanok2

Figure 1. Three types of Hanoks for structural monitoring 

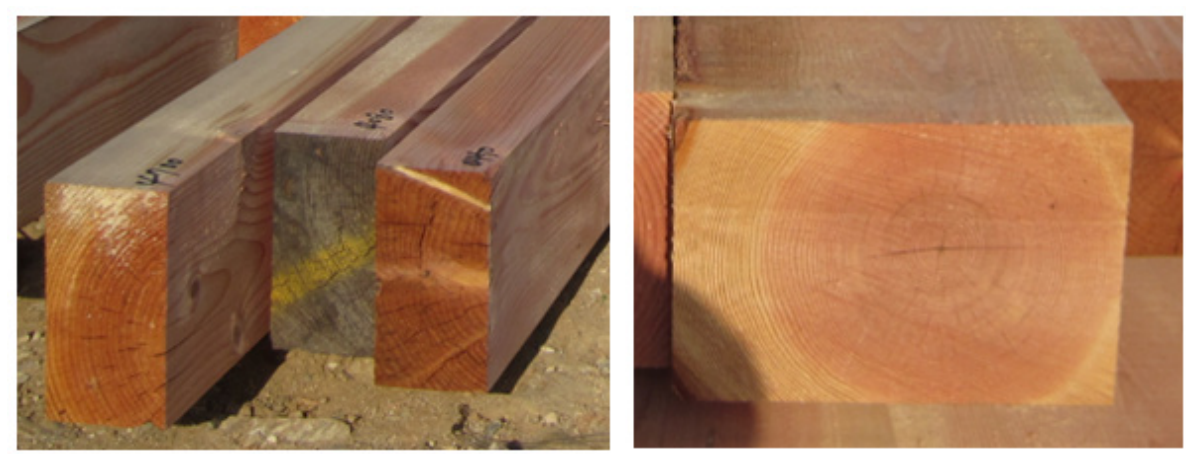

(a) Raw wood used in traditional Hanok
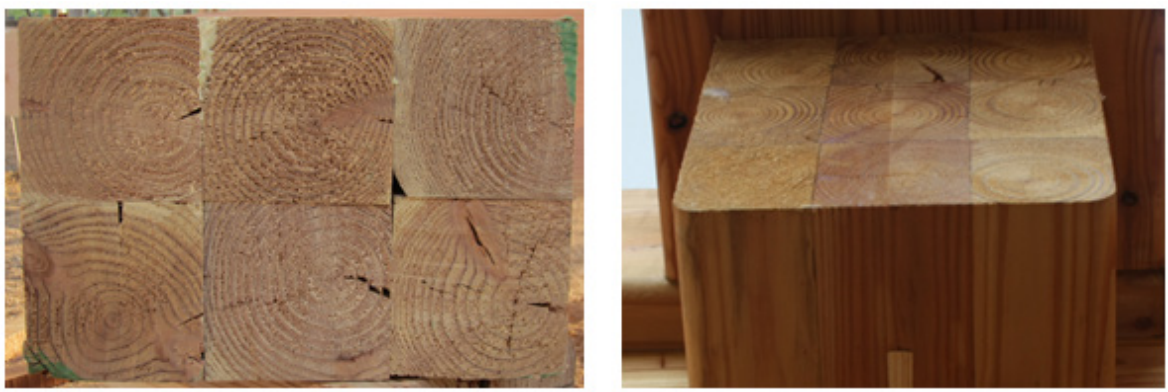

(b) Glued structural wood used in new-styled Hanok

Figure 2. Raw wood and glued structural wood.

Fig. 1(a) shows examples of a traditional Hanok built by traditional construction method and raw wood. Fig. 1(b) and Fig. 1(c) show new-styled Hanoks built by modernized construction method and glued structural wood. Fig 2(a) shows raw wood used in traditional Hanok, and Fig 2(b) shows glued structural wood used in new-styled Hanok.

Researches on the timber structures have been carried out domestically and internationally. In Korea, researches were mainly carried out on the temple building, traditional Hanok, and palace building. Seo et al.[1] analyzed static and cyclic behavior of Korean traditional timber house with tenon joints under lateral load, and revealed that ancient Korean timber house has a significant nonlinear characteristics. Hwang et al.[2] extracted relationship between damping ratio and vibration amplitude of Korean traditional timber structure by shaking table test. Lee et al.[3], [4] evaluated load carrying capacity of Korean traditional timber structure according to various connection types.

In China, Kang et al.[5] studied static performance of mortise and tenon joint in their traditional timber structure. And Fang et al.[6], [7] performed shaking table test on an ancient Chinese timber structure and evaluated its load carrying capacity.

As researches on the new-styled Hanok, Kim [8] performed dynamic experiments on a two-storied $1 / 4$ scale Hanok and compared the results with the eigenvalue analysis and extracted dynamic characteristics of the new-styled Hanok. Wood, used as the structural members of Hanok has its demerits that it splits as it dries. Moisture content is the main influential factor to the splitting of wood. As for the researches on the moisture contents in timber structures,
Park et al.[9] evaluated distribution pattern of moisture contents in Korean traditional timber structure, and Kim [10, 11] monitored moisture contents and vertical deflection of both the traditional and the new-styled Hanok for about two years, and evaluated the relationship among wood types, relative humidity and moisture contents.

In this study, as the extension of the previous study done by the author[10, 11] I monitored the surface moisture contents and vertical deflection of both the traditional Hanok and the new-styled Hanok for about two and a half years, and analyzed the monitored data to establish the basic standard for the long-term maintenance and management of Hanok.

\section{Introduction of the Monitored Buildings}

The monitored test-bed Hanoks are located two cities, that is Yongin and Seoul. Seoul is the capital city of Korea, and Yongin is located about $40 \mathrm{~km}$ south of Seoul. The traditional Hanok as shown in Fig. 1(a) and the new-styled Hanok1 as shown in Fig. 1(b) are located in Myongji University, Yongin. The new-styled Hanok2 is located in Eunpyeong Hanok town, which is about $10 \mathrm{~km}$ north of center of Seoul. Geometric positions of these two cities are about 127 degrees east longitude and 37 degrees north latitude as shown in Fig. 3. Yongin and Seoul has a moderate climate with four distinct seasons. Their annual average temperature is about $12^{\circ} \mathrm{C}$ and annual average precipitation is about $1,300 \mathrm{~mm}$.

The monitored buildings are composed of three Hanoks. One is a one-story traditional Hanok built by traditional 
construction method as shown in Fig. 1(a) and Fig. 4(a). Another is a two-storied new-styled Hanok, called new-styled Hanok1, built by modernized construction method as shown in Fig. 1(b) and Fig. 4(b). The other is a two-storied new-styled Hanok, called new-styled Hanok2, built also by modernized construction method as shown in Fig. 1(c) and Fig. 4(c). The wood type, joint type and year of completion of these three Hanoks are summarized in Table 1. Raw wood was used for the traditional Hanok as its main structural members, whereas, glued structural wood was used for the two new-styled Hanoks. The joint type of traditional Hanok is mainly traditional mortise and tenon joint as shown in Fig. 5(a), whereas, that of the new-styled Hanoks is mainly steel plate and bolt joint as shown in Fig. 5(b) (c). Traditional Hanok and new-styled Hanok1 were completed in May 2012, whereas new-styled Hanok2 was completed in August 2013.

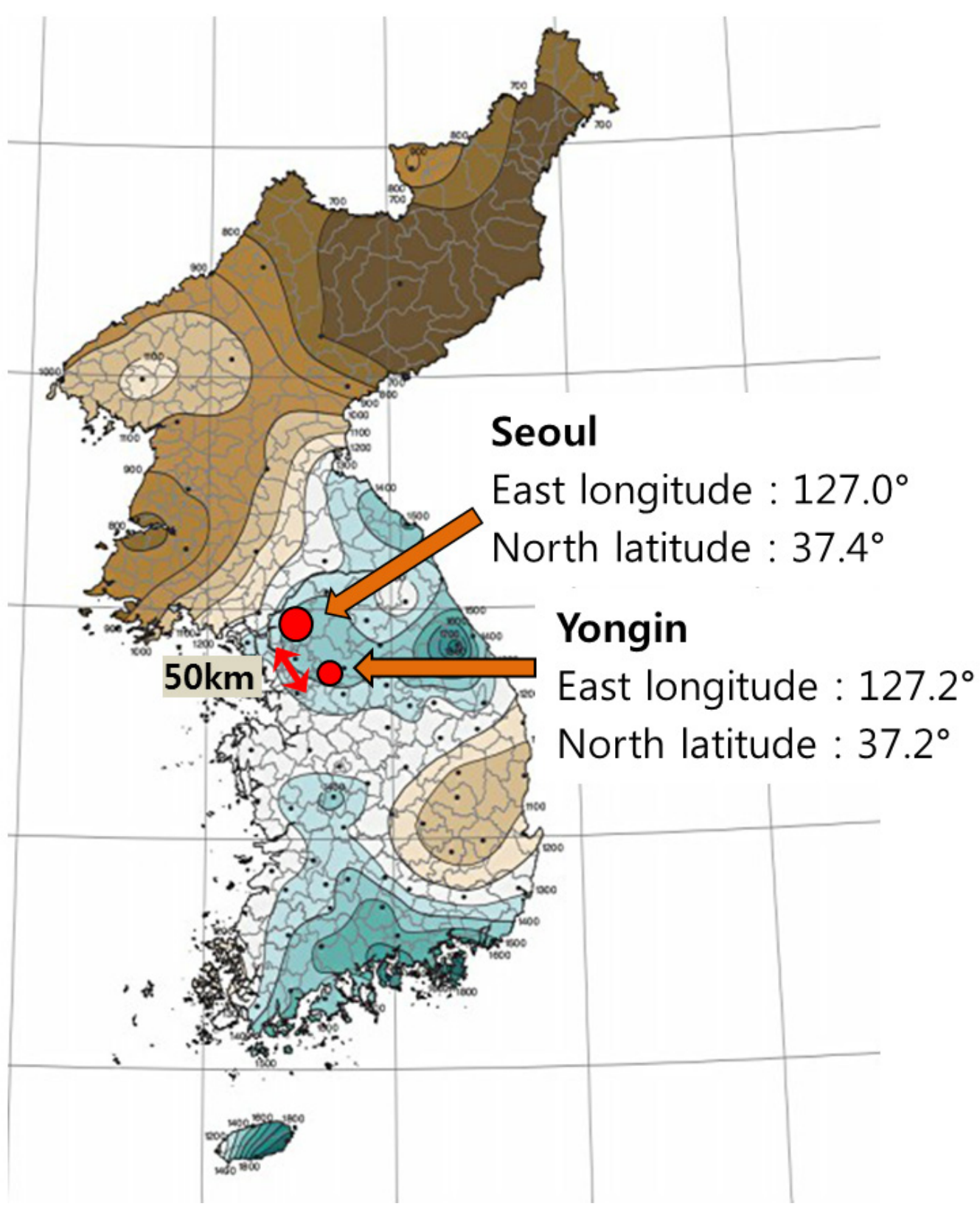

Figure 3. Location of test-bed Hanoks. 

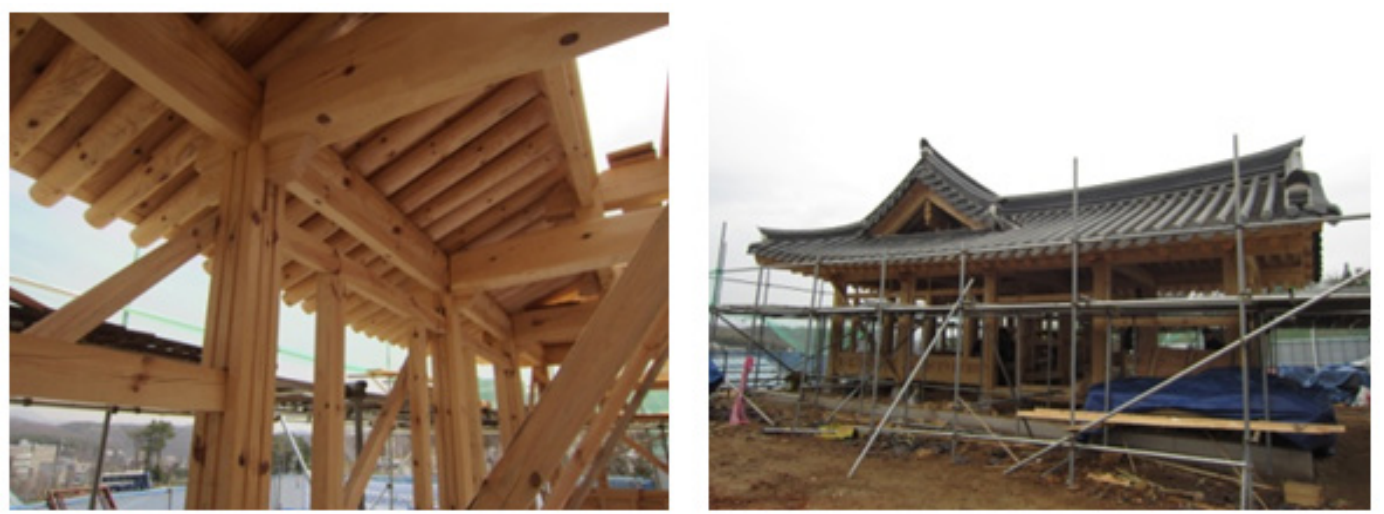

(a) Construction of traditional Hanok
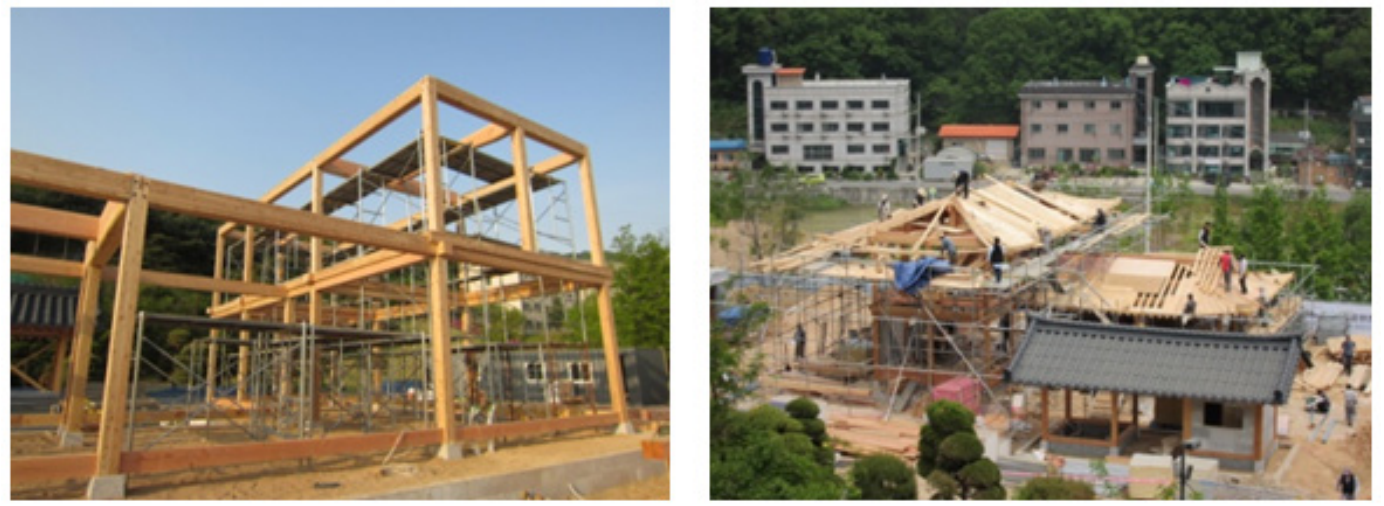

(b) Construction of new-styled Hanok1
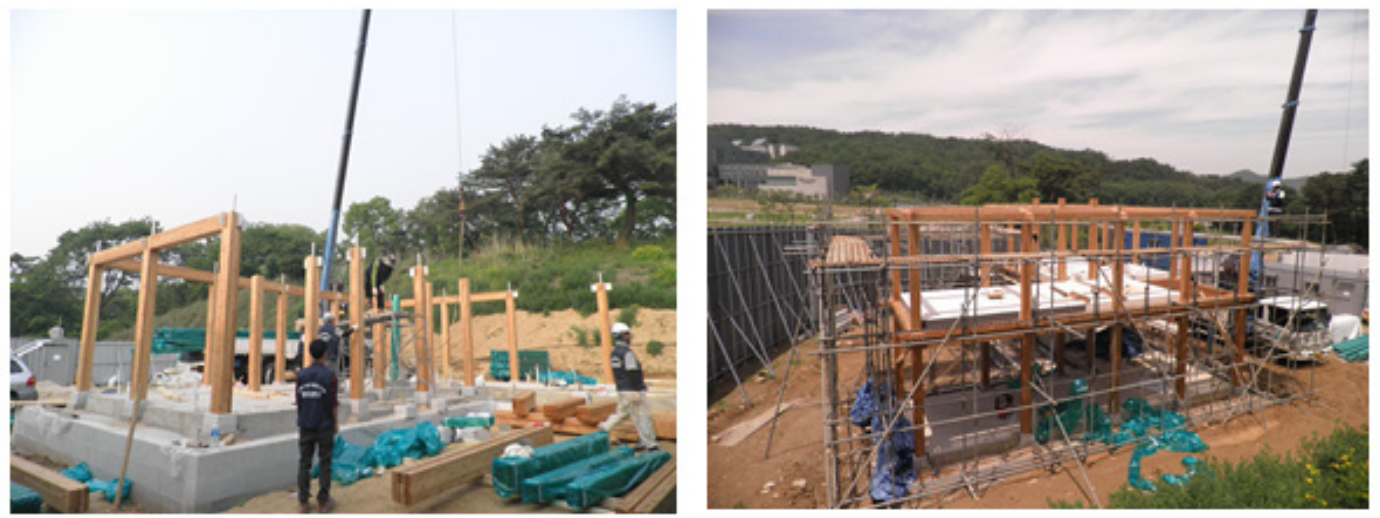

(c) Construction of new-styled Hanok2

Figure 4. Construction process of three test-bed Hanoks.

Table 1. Information for the Three Test-bed Hanoks

\begin{tabular}{|c|c|c|c|}
\hline Type of Hanok & Wood type & Joint type & Year of completion \\
\hline Traditional Hanok & raw wood & mortise and tenon joint & 2012.05 \\
\hline New-styled Hanok1 & glued structural wood & steel plate and bolt joint & 2012.05 \\
\hline New-styled Hanok2 & glued structural wood & steel plate and bolt joint & 2013.08 \\
\hline
\end{tabular}



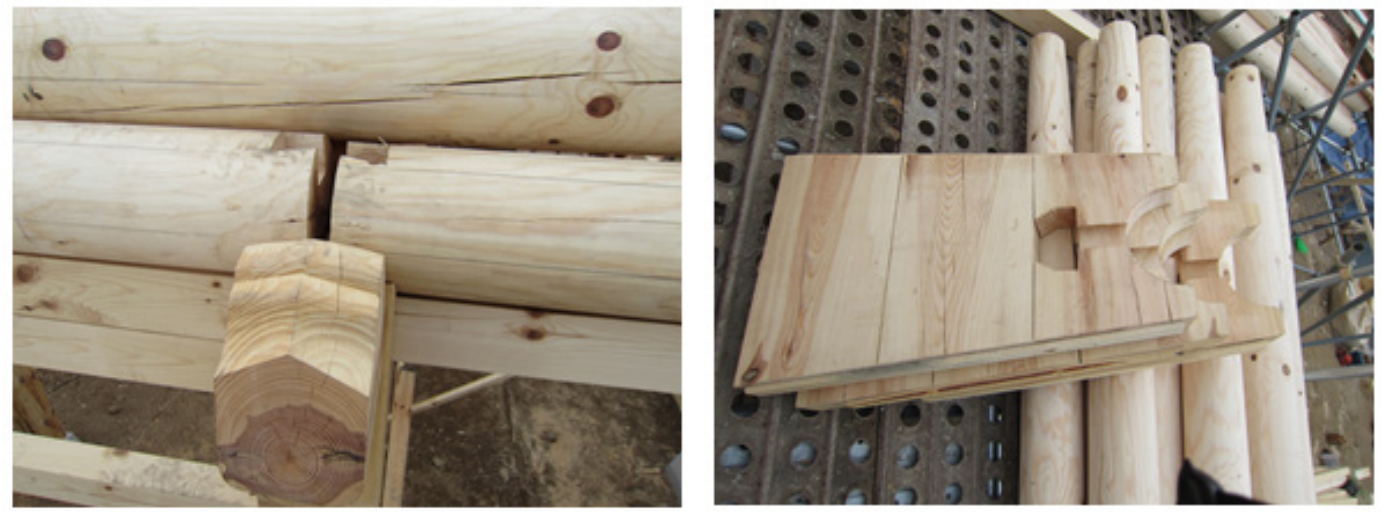

(a) Mortise and tenon joints in traditional Hanok
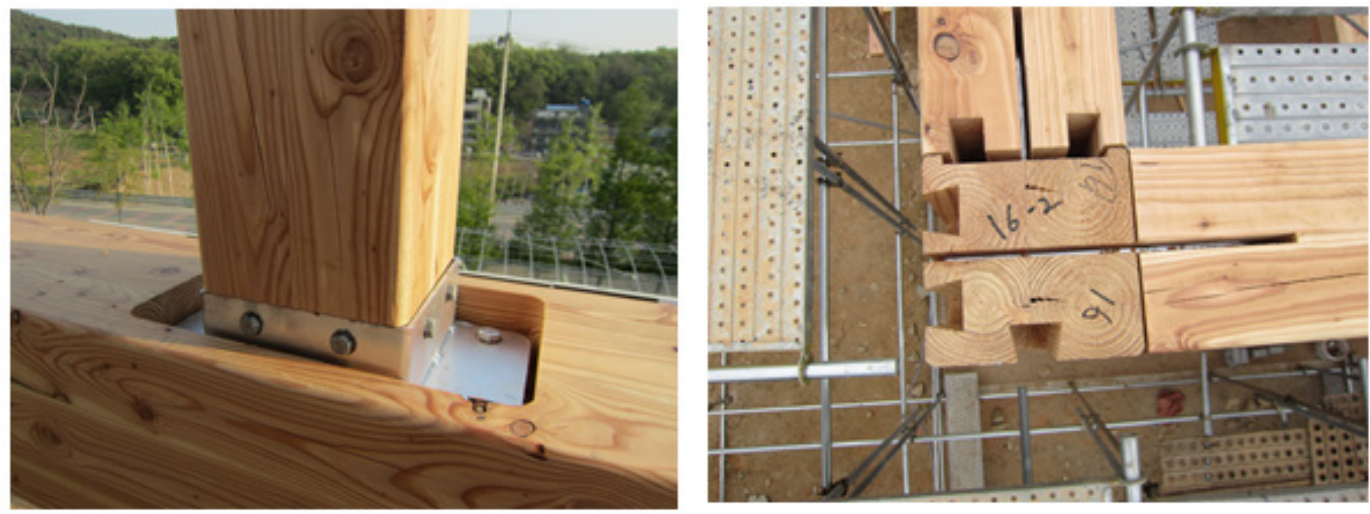

(b) Steel plate and bolt joints in new-styled Hanok1
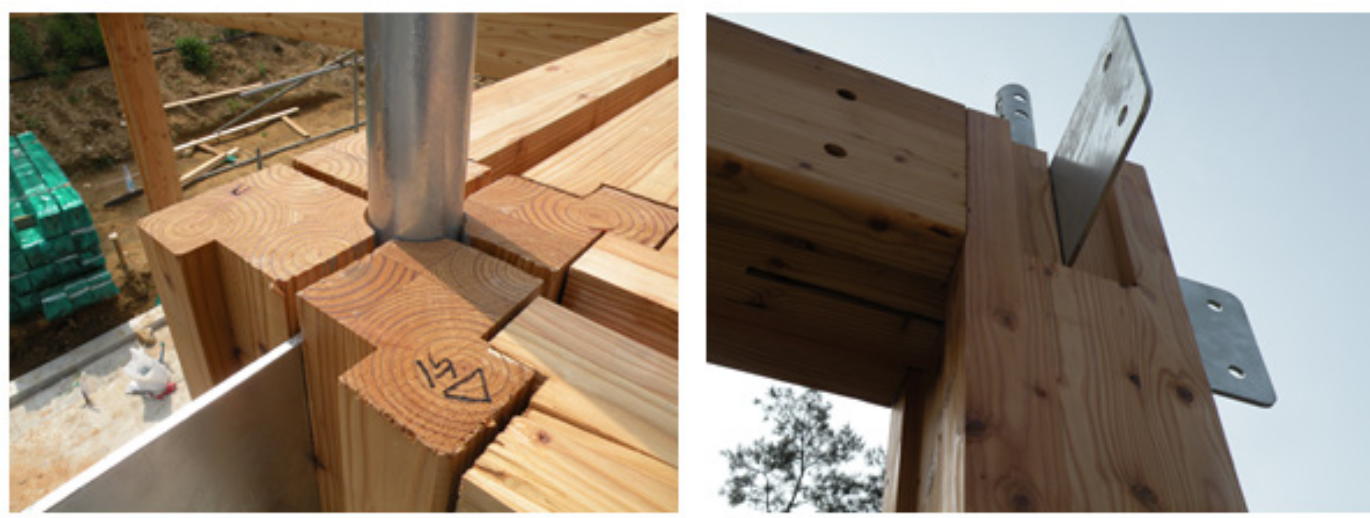

(c) Steel plate and bolt joints in new-styled Hanok2

Figure 5. Joint types of three test-bed Hanoks.

\section{Monitoring Plan}

Structural monitoring for the traditional Hanok and new-styled Hanok1 were carried out since August 2012, and that of the new-styled Hanok2 was carried out since January 2014. The structural monitoring is scheduled to extend until October 2016. In this paper, the monitored data until February 2015 is analyzed.

Fig. 6 shows monitored members for each three test-bed Hanoks. Surface moisture contents of columns were measured at their half height. Long-term deflections were monitored for horizontal structural members of roof, that is, angle rafters, plane rafters, and beams. Vertical deflections were monitored by measuring distance from the reference point to the target point using laser distance measuring device. The reference point is located just below of each target point. Fig. 7(a) shows scenes of measuring moisture contents and vertical deflection. The measuring device for moisture contents is shown in Fig. 7(b), it is an electric-resistant device from TESTO Inc., and its model name is $606-2$ with measurement error $\pm 1 \%$. The measuring device for deformation is shown in Fig. 7(c), it is from Leica Inc., and its model name is DISTO D5 with measurement error $\pm 1 \mathrm{~mm}$. Monitored members for moisture contents and vertical deflections are summarized in Table 2 and Table 3 , respectively. 
The shapes of section of angle rafters and plane rafters for three Hanoks are the same. They have circular section. Section diameters of angle rafters and plane rafters of traditional Hanok and new-styled Hanok1 is $120 \mathrm{~mm}$, but those of the new-styled Hanok2 is $110 \mathrm{~mm}$.
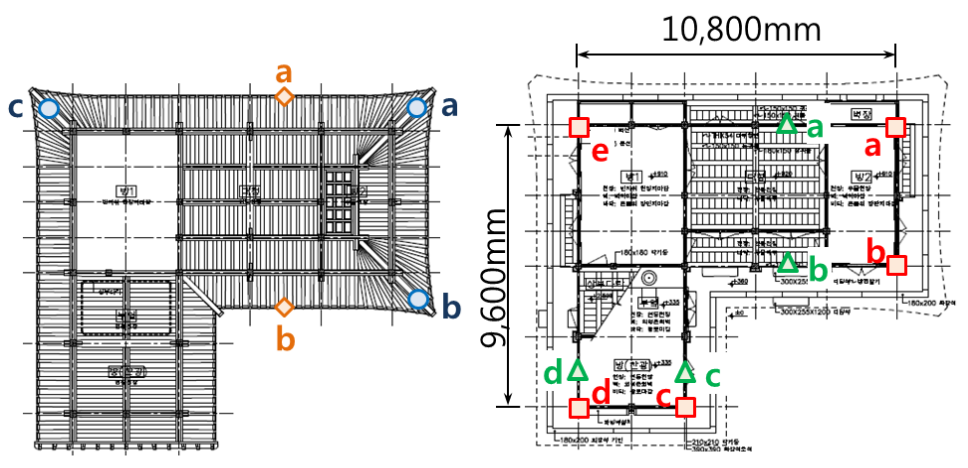

(a) Traditional Hanok

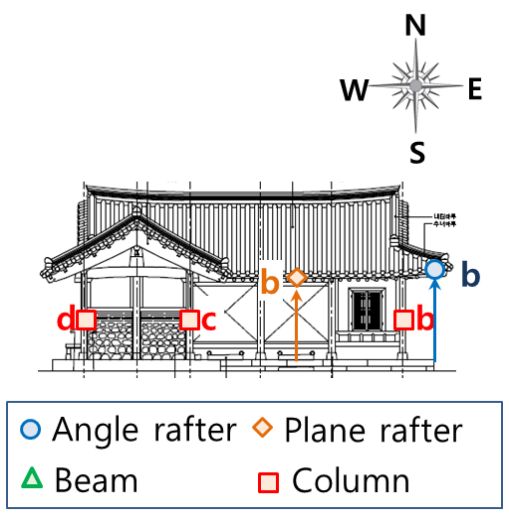

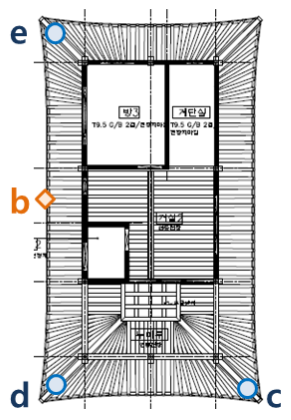
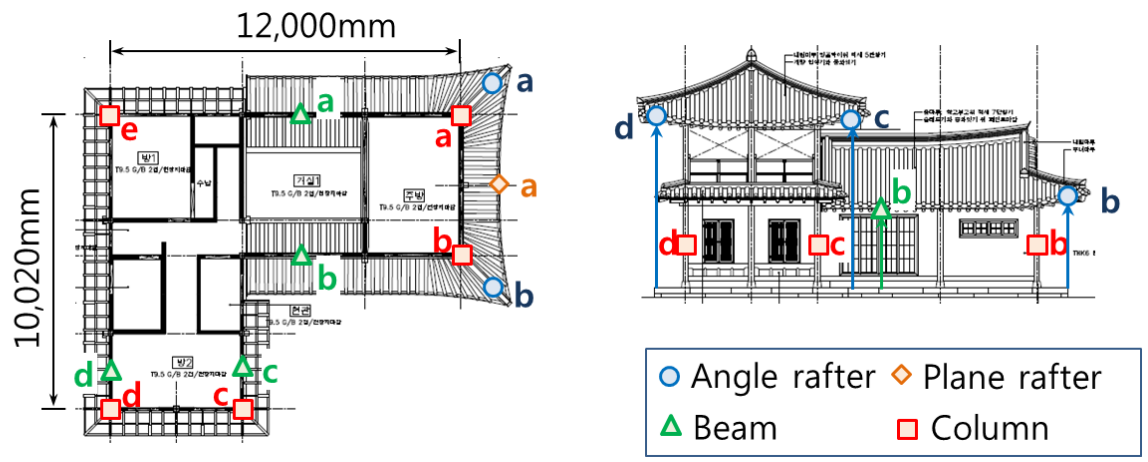

(b) New-styled Hanok1
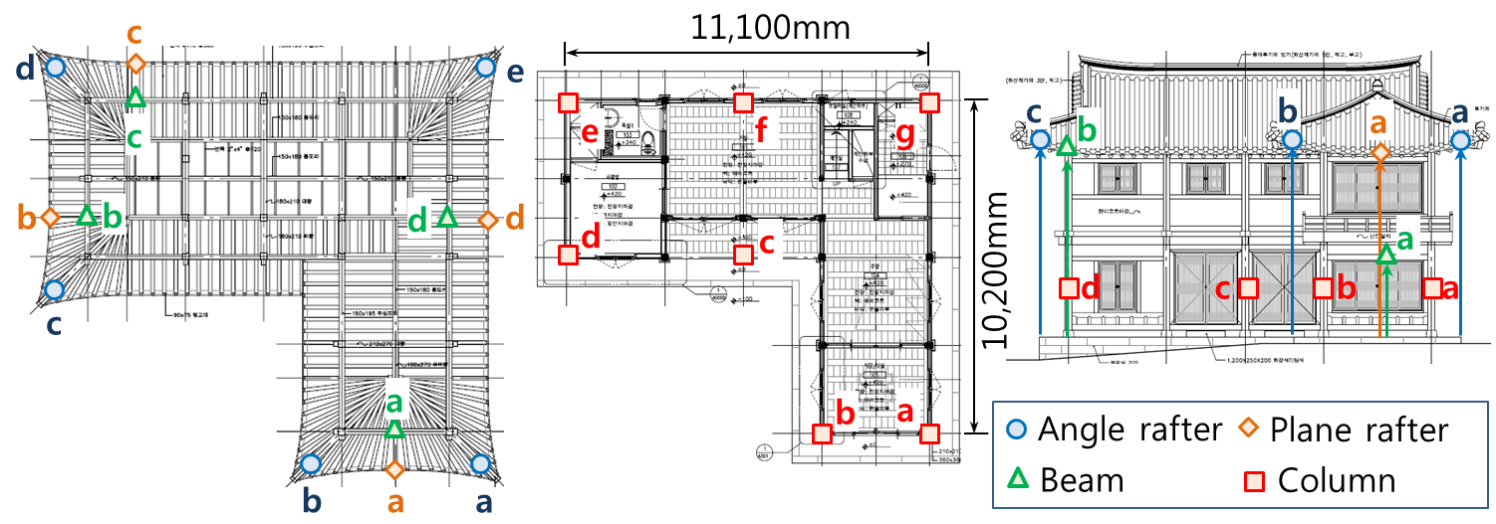

(c) New-styled Hanok2

Figure 6. Plan and elevation views and position of monitored members 

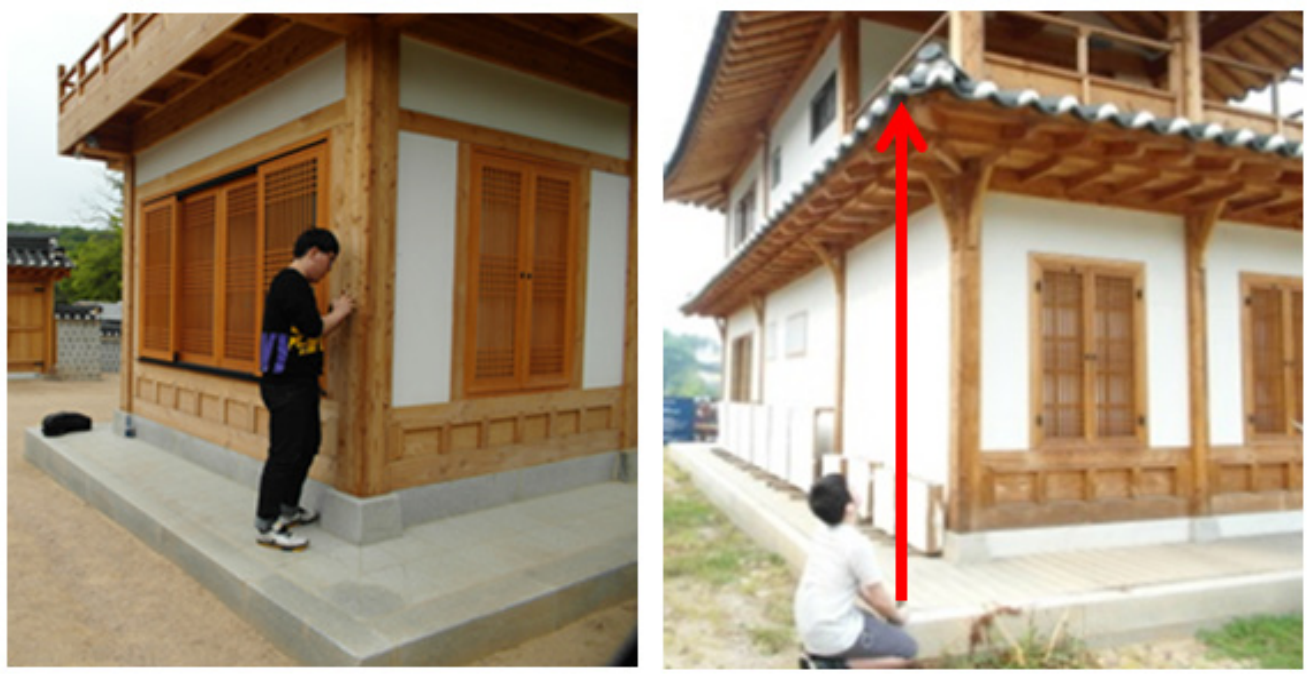

(a) Measuring of moisture contents and roof deflection
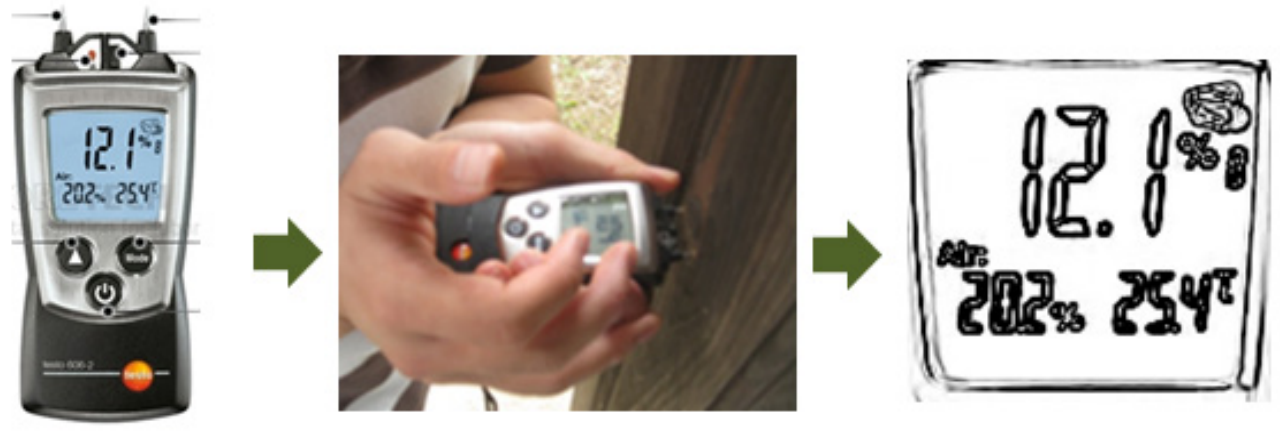

(b) Equipment for measuring moisture contents
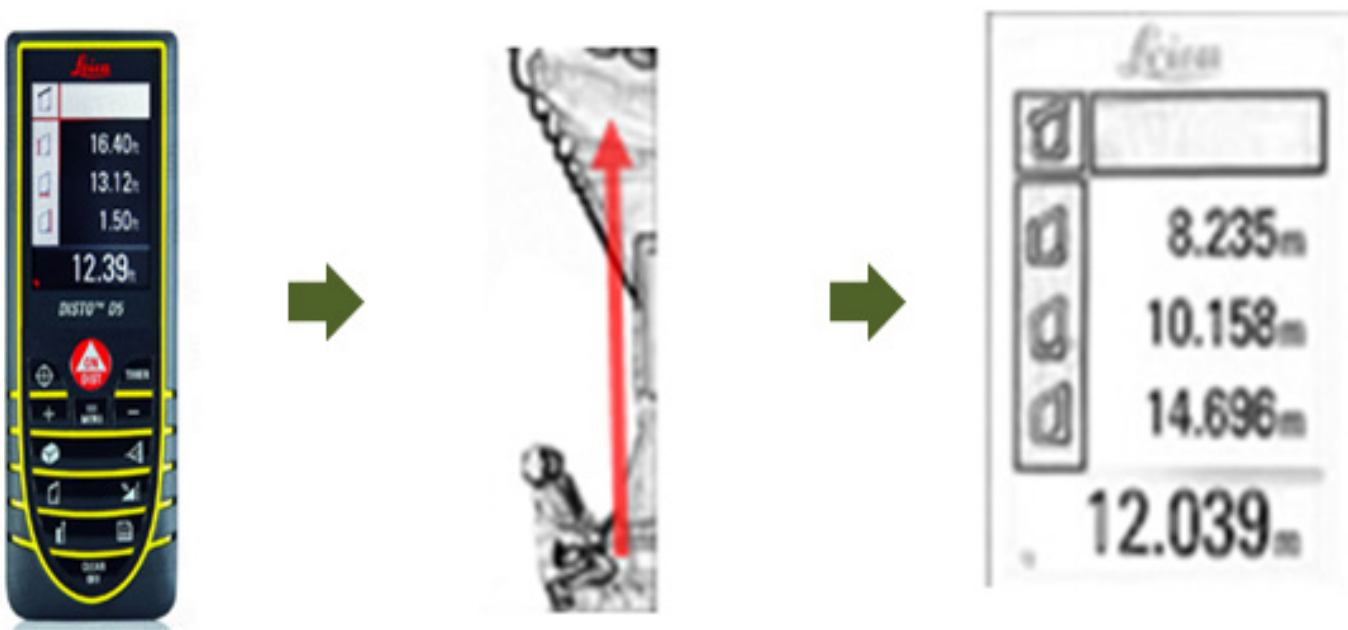

(c) Equipment for measuring deflection

Figure 7. Measuring of moisture contents and deformation 
Table 2. Monitored Members for Moisture Contents

\begin{tabular}{|c|c|c|c|}
\hline \multirow{2}{*}{ Type of Hanok } & \multicolumn{2}{|c|}{ Number of monitored columns } & Northern \\
size (mm) & Southern & 2 & $210 \times 210$ \\
\cline { 2 - 4 } & 3 & 2 & $180 \times 180$ \\
\hline Traditional Hanok & 3 & 3 & $210 \times 210$ \\
\hline New-styled Hanok1 & 4 & 3 & 210 \\
\hline
\end{tabular}

Table 3. Monitored Members for Roof Deflection

\begin{tabular}{|c|c|c|c|}
\hline Type of Hanok & Angle rafter & Plane rafter & 2 \\
\hline Traditional Hanok & 3 & 2 & 4 \\
\hline New-styled Hanok1 & 5 & 43 & 4 \\
\hline New-styled Hanok2 & 5 & 43 \\
\hline
\end{tabular}

\section{Analysis of the Monitored Results}

\subsection{Moisture Contents and Column Location}

The moisture contents were analyzed based on three criteria that is column location to the sun, wood type, and relative humidity. The wood used for the three test-bed Hanoks is domestic larch wood.

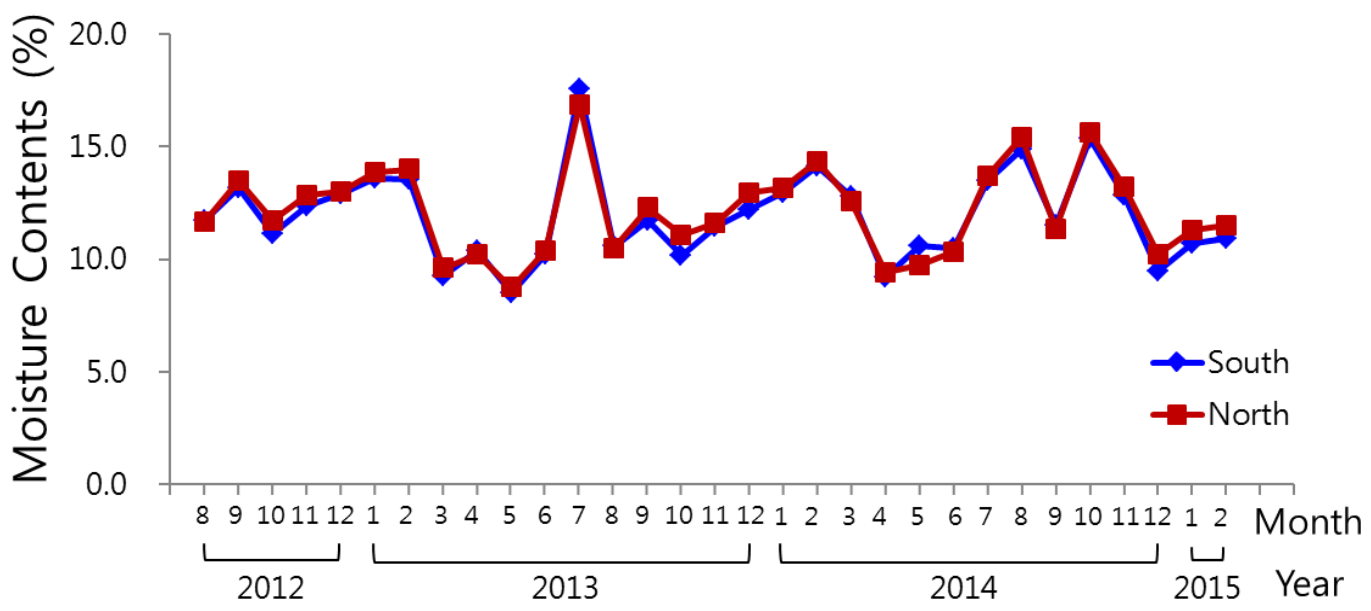

(a) Traditional Hanok

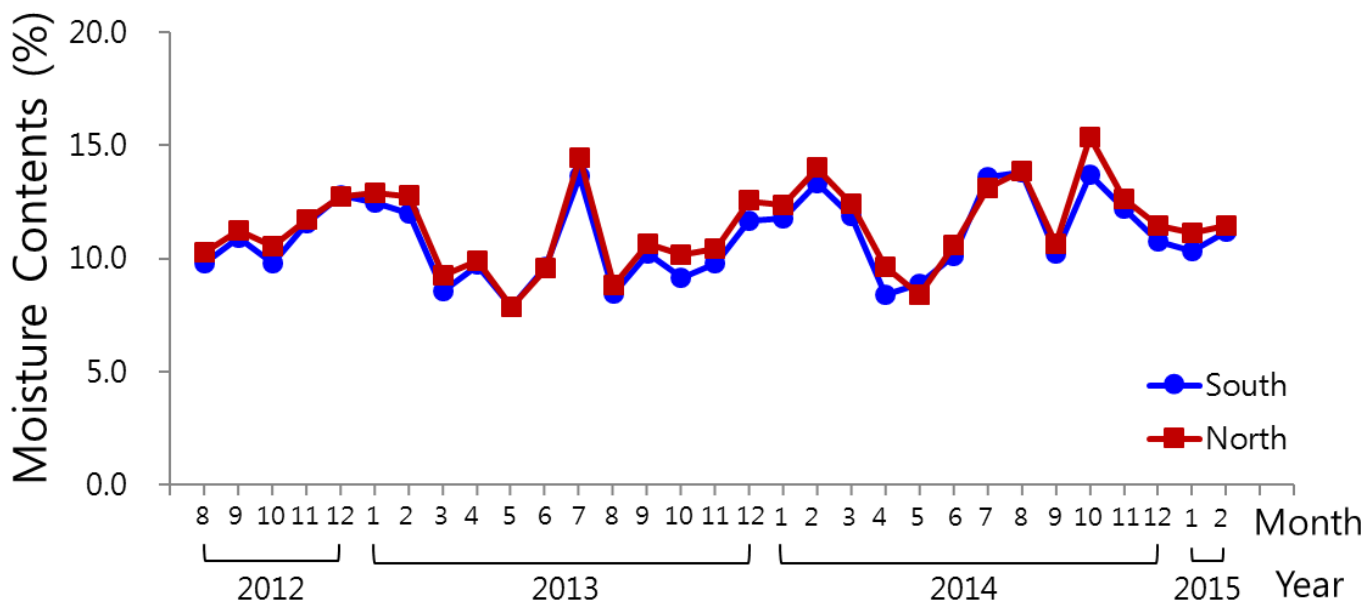

(b) New-styled Hanok1 


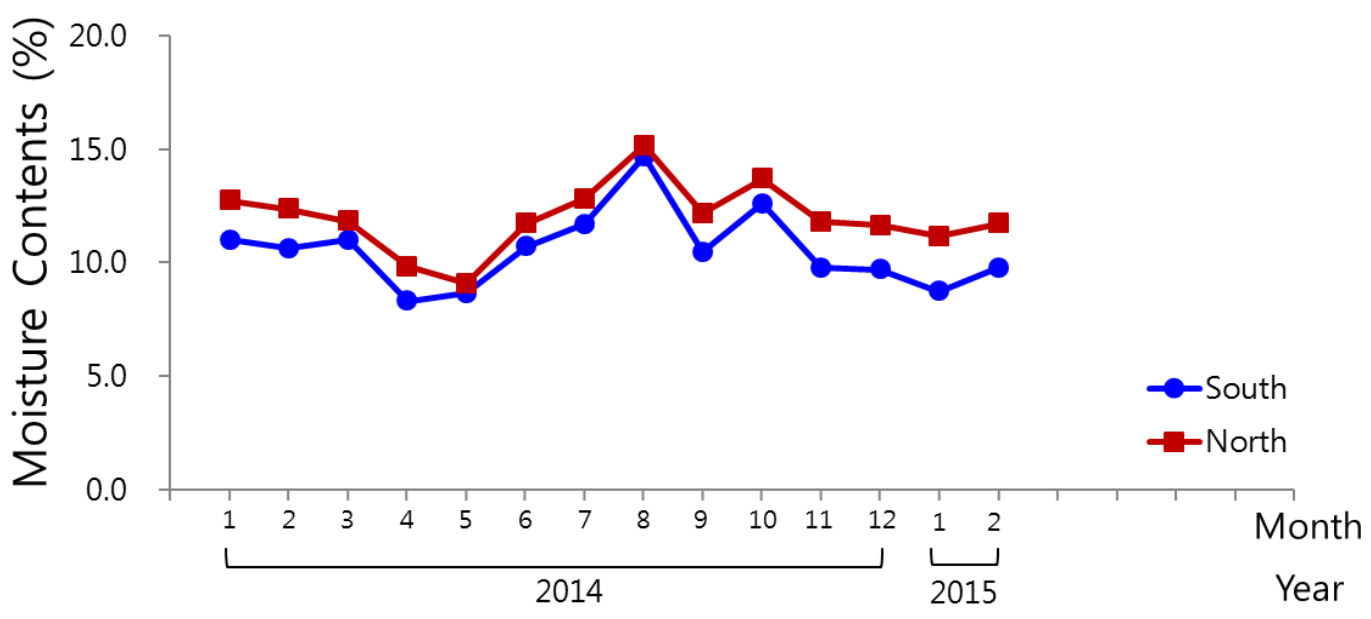

(c) New-styled Hanok2

Figure 8. Comparison of moisture contents according to column location to the sun for three test-bed Hanoks

Fig. 8 shows moisture contents according to column location for the entire monitoring period. The columns at the north side of the building show slightly more moisture contents than those at the south side of building. Table 4 shows average moisture contents according to column location. The difference of moisture contents between southern and northern columns vary from $0.22 \%$ to $1.43 \%$. It is $1.43 \%$ in the new-styled Hanok 2 and $0.48 \%$ in the new-styled Hanok 1 and $0.25 \%$ in the traditional Hanok. Though, the difference is small compared to the measurement error of $\pm 1 \%$ of measuring equipment, the moisture contents of the northern columns are higher than those of the southern columns throughout most of the monitoring period as shown in Fig. 8. From this fact it can be deduced that the moisture contents are influenced by the sunlight in a certain degree.

Table 4. Comparison of Moisture Contents for Three Test-Bed Hanoks

\begin{tabular}{|c|c|c|c|}
\hline \multirow{2}{*}{ Type of Hanok } & \multicolumn{3}{|c|}{ Average moisture content (\%) } \\
\cline { 2 - 4 } & $\begin{array}{c}\text { South } \\
\text { (A) }\end{array}$ & $\begin{array}{c}\text { North } \\
\text { (B) }\end{array}$ & $\begin{array}{c}\text { Difference } \\
\text { (B - A) }\end{array}$ \\
\hline Traditional Hanok & 11.95 & 12.17 & 0.22 \\
\hline New-styled Hanok1 & 10.92 & 11.40 & 0.48 \\
\hline New-styled Hanok2 & 10.58 & 12.01 & 1.43 \\
\hline
\end{tabular}

\subsection{Moisture Contents and Wood Type}

In Fig. 9, moisture contents between traditional Hanok and new-styled Hanok1 is compared. These two Hanoks are different in their wood type. The traditional Hanok used raw wood, whereas the new-styled Hanok used glued structural wood as their main structural members. The traditional Hanok with raw wood showed more moisture contents than the new-styled Hanok for most of monitoring period.

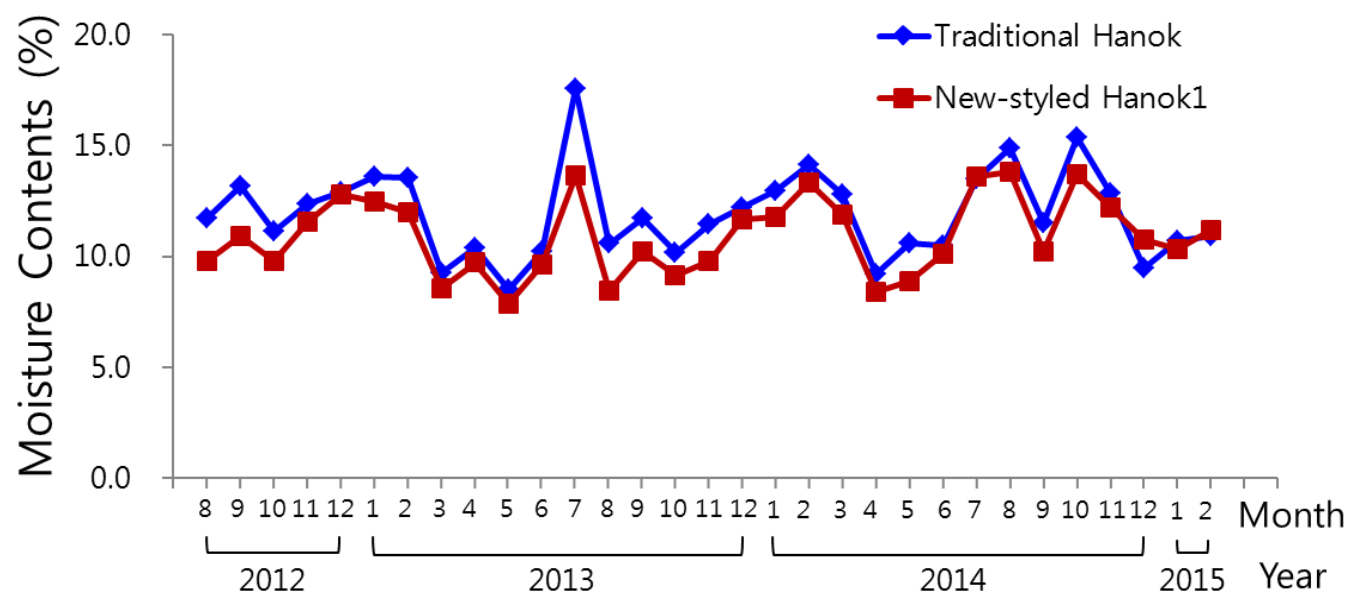

(a) Southern columns 


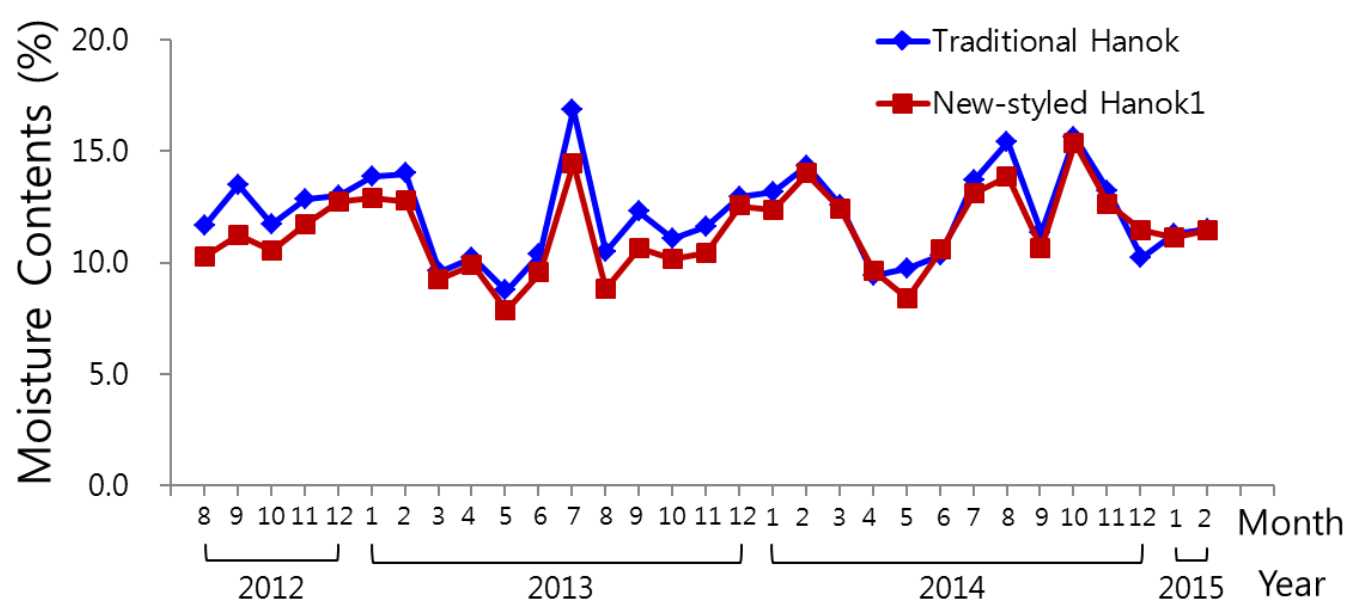

(b) Northern columns

Figure 9. Comparison of mean moisture contents between traditional Hanok and new-styled Hanok1 with different wood type

In Table 5, the moisture contents of the three test-bed Hanoks are compared numerically. The moisture contents of the traditional Hanok turned out higher than that of the average moisture contents of the new-styled Hanok1 and new-styled Hanok2, that is, $1.20 \%$ in the southern columns and $0.47 \%$ in the northern columns. From this fact it can be deduced that the glued structural wood, which is made of small size rectangular wood, contains less moisture content than big sized raw wood from manufacturing, and this initial gap maintains thereafter.

Table 5. Comparison of Moisture Contents According to Wood Type

\begin{tabular}{|c|c|c|}
\hline \multirow{2}{*}{ Type of Hanok } & \multicolumn{2}{|c|}{ Average moisture contents (\%) } \\
\cline { 2 - 3 } & South & North \\
\hline Traditional Hanok (A) & 11.95 & 12.17 \\
\hline New-styled Hanok1 (B) & 10.92 & 11.40 \\
\hline New-styled Hanok1 (C) & 10.58 & 12.01 \\
\hline difference $(A-(B+C) / 2)$ & 1.20 & 0.47 \\
\hline
\end{tabular}

\subsection{Moisture Contents and Relative Humidity}

It can be easily deduced that there may be somewhat linear relationship between surface moisture contents of wood and relative humidity. The region where the monitored buildings are located has four distinct seasons, where in summer high temperature and high humidity and in winter cold temperature and low humidity. Fig. 10 shows the variation of the mean relative humidity and the mean moisture contents of both the traditional Hanok and the new-styled Hanok1. In a rough way, they show similar variation pattern. Table 6 shows seasonal mean temperature and mean relative humidity numerically.

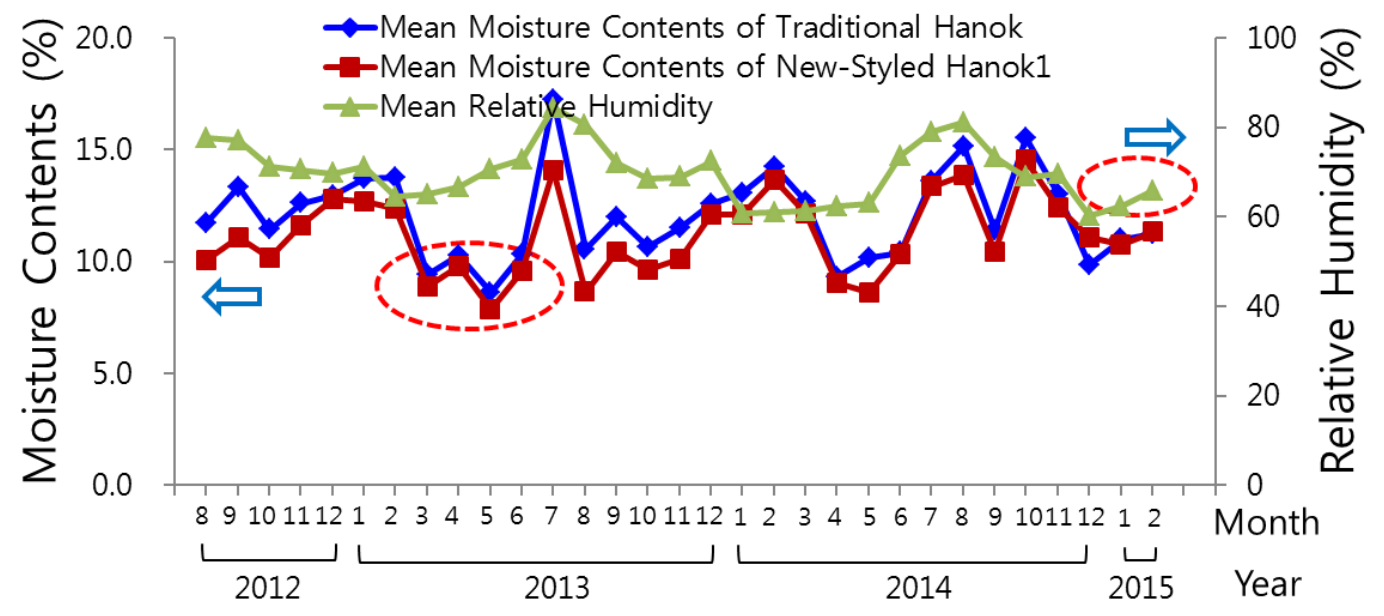

Figure 10. Relationship between moisture contents and relative humidity for both traditional Hanok and new-styled Hanok1 
Table 6. Seasonal Mean Temperature and Mean Relative Humidity

\begin{tabular}{|c|c|c|c|c|}
\hline Item & Spring & Summer & Fall & Winter \\
\hline mean temperature $\left({ }^{\circ} \mathrm{C}\right)$ & 11.9 & 25.3 & 14.5 & -1.0 \\
\hline mean relative humidity (\%) & 64.9 & 78.5 & 71.2 & 65.4 \\
\hline
\end{tabular}

\subsection{Vertical Deflection of Main Lateral Members}

From Fig. 11 to Fig. 13, deflections of angle rafters and plane rafters for the three test-bed Hanoks are showed graphically throughout the entire monitoring period. Angle rafters and plane rafters showed meaningful deflections, whereas beams showed little deflection. Although there are small fluctuations in the graph, the overall trends show gradual deformation as time goes by. In the graph, regression curves are also drawn to predict future deflection trends.

In Table 7, the deflections of angle rafters are summarized. The mean vertical deflection of angle rafters, located on the corners of eaves, is $11.6 \mathrm{~mm}$ in the traditional Hanok and $2.6 \mathrm{~mm}$ and $5.8 \mathrm{~mm}$ both in the new-styled Hanok1's 1st and 2nd roofs respectively, and $2.1 \mathrm{~mm}$ in the new-styled Hanok2.

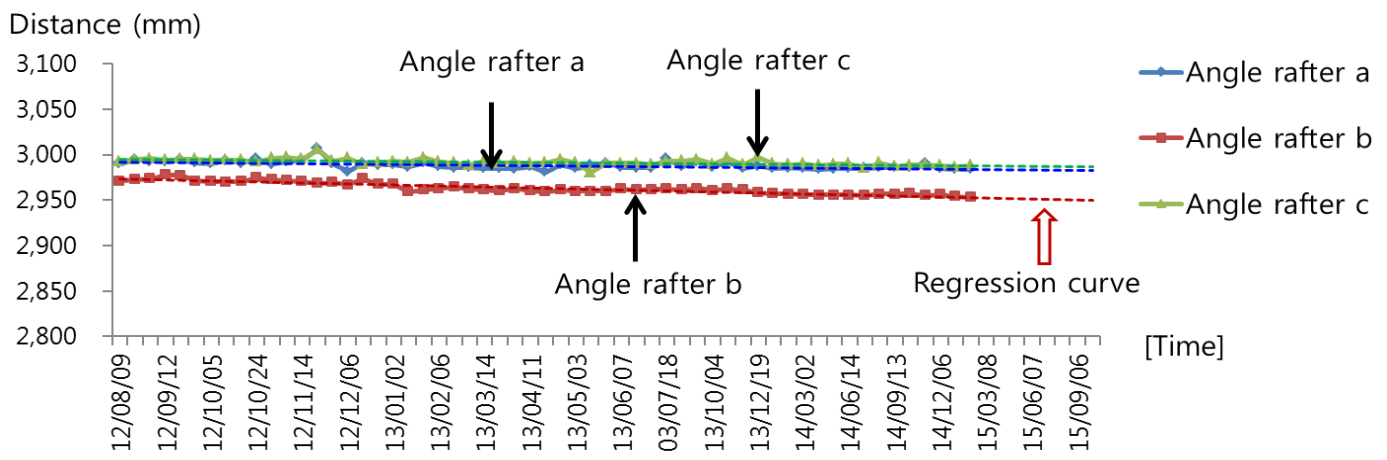

(a) Deflection of angle rafters

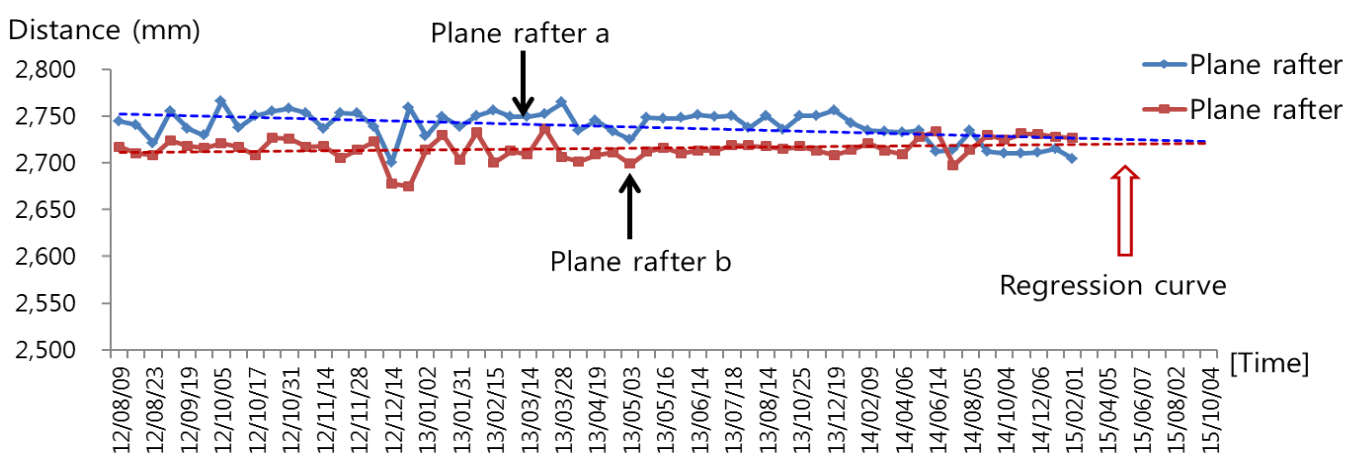

(b) Deflection of plane rafters

Figure 11. Deflection of traditional Hanok

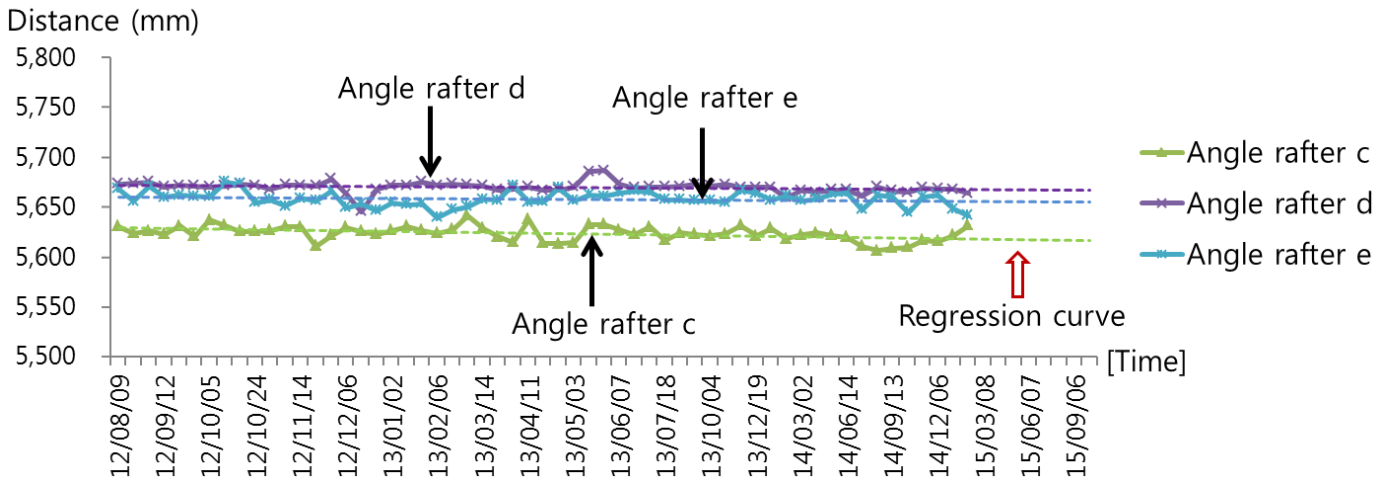

(a) Deflection of angle rafters 


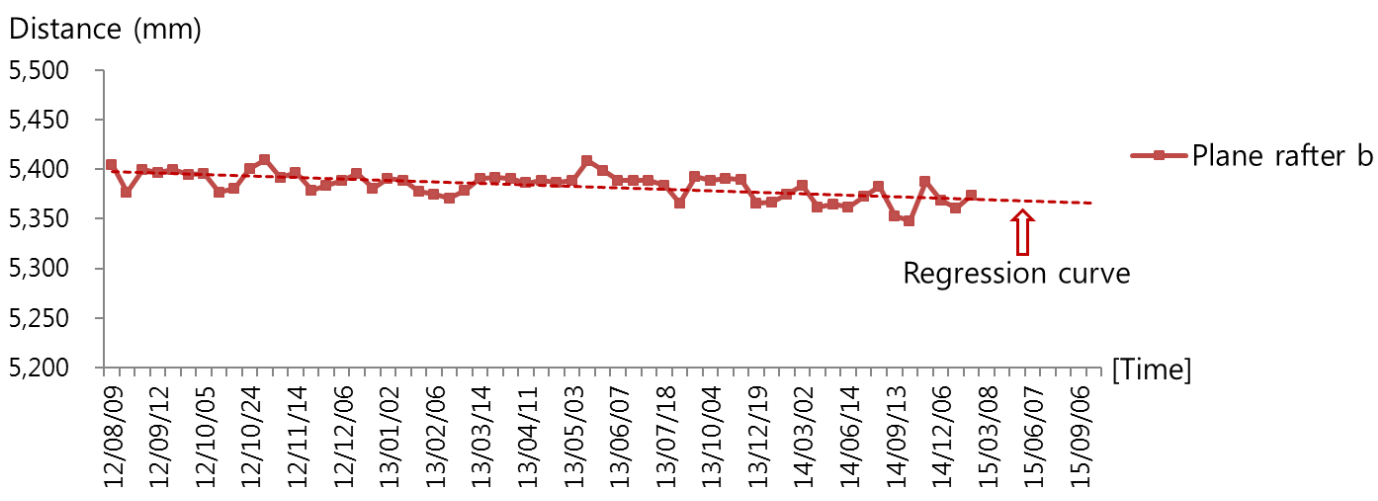

(b) Deflection of plane rafters

Figure 12. Deflection of new-styled Hanok1

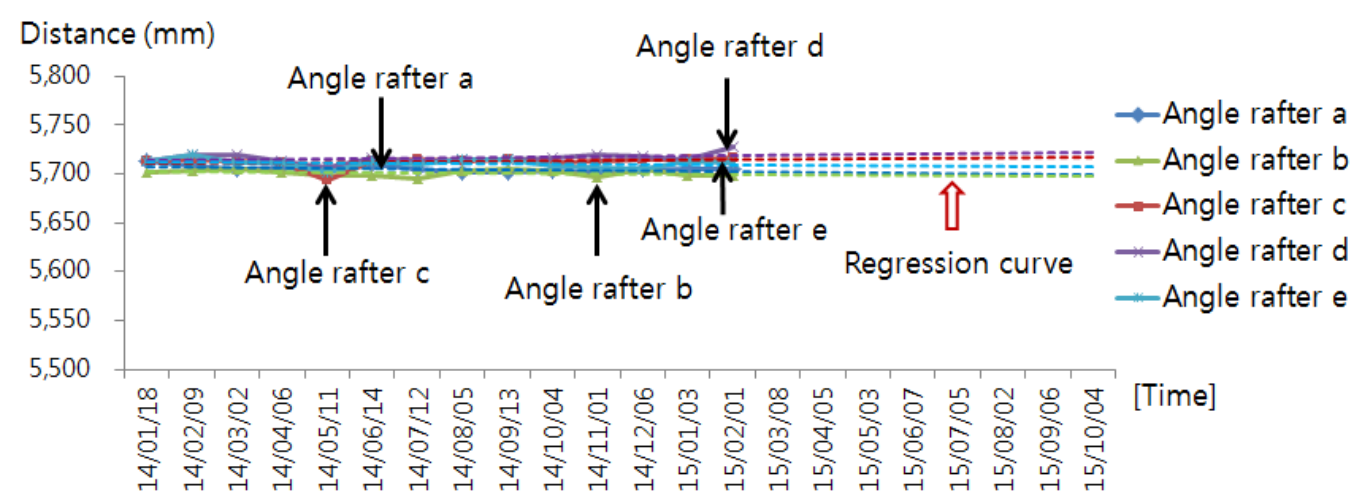

(a) Deflection of angle rafters

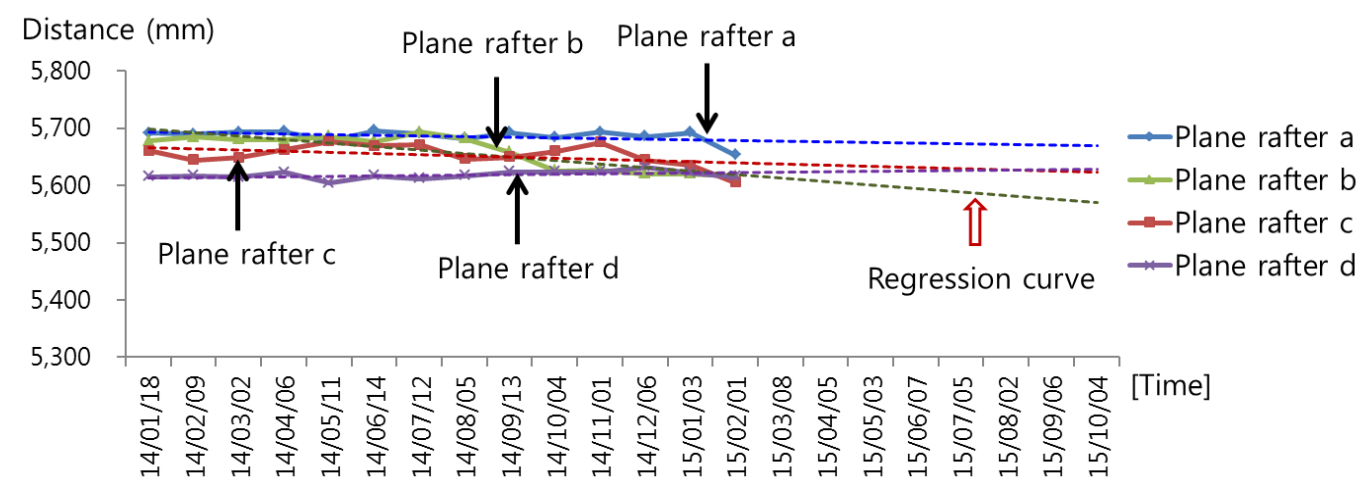

(b) Deflection of plane rafters

Figure 13. Deflection of new-styled Hanok2

The angle rafters of traditional Hanok showed 2 5 times more deflection than those of the new-styled Hanoks. The roof weight of the traditional Hanok weigh about 2 3 times more than those of the new-styled Hanoks, so the traditional Hanok showed more long-term deflection than the new-styled Hanok in angle rafters.

In Table 8, the deflections of plane rafters are summarized. The mean vertical deflections of plane rafters, located between the angle rafters, show similar value for all the three test-bed Hanoks. The plane rafters showed more deflection than the angle rafters and this can be explained by considering supporting members. Angle rafters are supported by columns which have little vertical shortening, whereas, plane rafters are supported by beams which show relatively large deflections than columns. So, the deflections of the plane rafters were magnified by the deformation of their supporting members. 
Table 7. Vertical Deflection of Angle Rafters for Three Test-Bed Hanoks

\begin{tabular}{|c|c|c|c|c|}
\hline Type of Hanok & Roof position & Angle rafter & Deflection(mm) & Mean deflection $(\mathrm{mm})$ \\
\hline \multirow{3}{*}{ Traditional Hanok } & \multirow{3}{*}{$1^{\text {st }}$ roof } & $\mathrm{a}$ & 8.6 & \multirow{3}{*}{11.6} \\
\hline & & $\mathrm{b}$ & 19.4 & \\
\hline & & $\mathrm{c}$ & 6.8 & \\
\hline \multirow{5}{*}{ New-styled Hanok1 } & \multirow{2}{*}{$1^{\text {st }}$ roof } & $\mathrm{a}$ & 1.5 & \multirow{2}{*}{2.6} \\
\hline & & $\mathrm{b}$ & 3.8 & \\
\hline & \multirow{3}{*}{$2^{\text {nd }}$ roof } & $\mathrm{c}$ & 4.8 & \multirow{3}{*}{5.8} \\
\hline & & d & 4.8 & \\
\hline & & $\mathrm{e}$ & 8.0 & \\
\hline \multirow{5}{*}{ New-styled Hanok2 } & \multirow{5}{*}{$2^{\text {nd }}$ roof } & a & 3.7 & \multirow{5}{*}{2.1} \\
\hline & & $\mathrm{b}$ & 2.9 & \\
\hline & & $\mathrm{c}$ & -0.5 & \\
\hline & & d & 0.0 & \\
\hline & & $\mathrm{e}$ & 4.3 & \\
\hline
\end{tabular}

Table 8. Vertical Deflection of Plane Rafters for Three Test-Bed Hanoks

\begin{tabular}{|c|c|c|c|c|}
\hline Type of Hanok & Roof position & Plane rafter & Deflection $(\mathrm{mm})$ & Mean deflection (mm) \\
\hline \multirow{2}{*}{ Traditional Hanok } & \multirow{2}{*}{$1^{\text {st }}$ roof } & $\mathrm{a}$ & 40.1 & \multirow{2}{*}{21.5} \\
\cline { 3 - 4 } & & $\mathrm{b}$ & 2.9 & -6.5 \\
\hline \multirow{2}{*}{ New-styled Hanok1 } & $1^{\text {st }}$ roof & $\mathrm{a}$ & -6.5 & 25.9 \\
\cline { 2 - 4 } & $2^{\text {nd }}$ roof & $\mathrm{b}$ & 25.9 & \\
\hline \multirow{3}{*}{ New-styled Hanok2 } & \multirow{3}{*}{$2^{\text {nd }}$ roof } & $\mathrm{a}$ & 14.3 & \multirow{2}{*}{20.3} \\
\cline { 3 - 4 } & & $\mathrm{b}$ & 57.9 & \\
\cline { 3 - 4 } & & $\mathrm{c}$ & -2.6 & \\
\cline { 3 - 4 } & & $\mathrm{d}$ & & \\
\hline
\end{tabular}

\section{Conclusions}

In this study I performed structural monitoring of the Korean traditional timber structure, called Hanok, to acquire basic data for maintenance and management. The moisture contents and vertical deflections were measured during two and a half years for three test-bed Hanoks, and the monitored data were analyzed. The moisture contents were analyzed focused on their relationship to the column location to the sun, wood types and relative humidity. The vertical deflections of main structural members of roof were analyzed focused on roof weight and supporting members.

The columns at the north side of the building showed more moisture contents than those of the south side of the building. The traditional Hanok, which is made of raw wood showed more moisture contents than the new-styled Hanoks made of glued structural wood. As for the relationship between relative humidity and moisture contents, they showed similar variation pattern.

The vertical deflection of angle rafters, plane rafters and beams for three test-bed Hanoks were also measured for about two and a half years. Angle rafters and plane rafters showed meaningful deformation. It can be deduced that, the deformation are mainly affected by roof weight and supporting members. But for the detailed analysis, the deformation needs to be monitored for more monitoring period.

This research is scheduled to extend another two years. It is expected that total of four years of monitoring would explain the relationship among moisture contents, roof deformation, and material properties of wood.

\section{Acknowledgements}

This work was supported by a grant (14AUDP-B070934-02) from Urban and Architecture Research Program funded by Ministry of Land, Infrastructure and Transport Affairs of Korean Government.

\section{REFERENCES}

[1] J. M. Seo, I. K. Choi, J. R. Lee, "Static and cyclic behavior of wooden frames with tenon joints under lateral load", Journal of Structural Engineering, vol. 125, no. 3, pp. 344-349, Mar. 1999.

[2] J. G. Hwang, S. G. Hong, Y. W. Lee, S. J. Jung, "Natural Frequency Characteristics of Traditional Wooden Structure 
for Vibration Amplitude", Journal of the Architectural Institute of Korea : Structure \& Construction, vol. 25, no. 5, pp. 3-10, May. 2009.

[3] Y. W. Lee, B. S. Bae, S. G. Hong, J. G. Hwang, N. H. Kim, S. J. Jung, "An Analytical Modelling of the Beam-Direction Frame of Traditional Wood Structure System", Journal of the Architectural Institute of Korea : Structure \& Construction, vol. 22, no. 3, pp. 29-36, Mar. 2006.

[4] Y. W. Lee, S. G. Hong, J. G. Hwang, B. S. Bae, "Capacity of Lateral Load Resistance of Dori-Directional Frame with Jangbu-connection in Traditional Wood Structure System", Journal of the Architectural Institute of Korea : Structure \& Construction, vol. 23, no. 2, pp. 35-42, Feb. 2007.

[5] M. Kang, N. Yang, Q. Cha, "Studies on Static Performance of Mortise and Tenon Joint in Traditional Column and Tie Construction Timber Structure", Electric Technology and Civil Engineering (ICETCE), 2011 International Conference, pp. 6197-6200, 2001.

[6] D. P. Fang, S. Iwasaki, M. H. Yu, Q. P. Shen, Y. Miyamoto, H. Hikosaka, "Ancient Chinese Timber Architecture I:
Experimental Study", Journal of Structural Engineering, vol. 127, no. 11, pp. 1348-1357, Nov. 2001.

[7] D. P. Fang, S. Iwasaki, M. H. Yu, Q. P. Shen, Y. Miyamoto, H. Hikosaka, "Ancient Chinese Timber Architecture II : Dynamic Characteristics", Journal of Structural Engineering, vol. 127, no. 11, pp. 1358-1364, Nov. 2001.

[8] Y.M. Kim: Dynamic Experiments on a 1-4 Scale New-styled Korean Traditional Wooden House. Applied Mechanics and Materials, 2014, Vol 598: 743-746.

[9] C. H. Park, G. C. Kim, "Study on Moisture Contents Distribution of Wooden Post Member by Precise Monitoring in Un-Bong Confusion School", Journal of the Korea Furniture Society, vol. 21, no. 1, pp. 104-112, Jan. 2013.

[10] Y.M. Kim: Monitoring of Moisture Contents in Korean Traditional Wooden Houses. In Proceedings of the World Congress on Engineering 2014, London, England, June 2-4, 2014, pp.1298-1303.

[11] Y.M. Kim: Deformation Monitoring in Korean Traditional Test-bed Hanok in Myongji University, Civil Engineering and Architecture, vol.3, no.2, pp.38-42, 2015. 